\title{
KAJIAN PERTUMBUHAN CHLORELLA SP. PADA LIMBAH CAIR INDUSTRI SUSU
}

\author{
A Study of the Growth of Chlorella sp. in the \\ Industrial Dairy Wastewater
}

\author{
Yudhi Soetrisno Garno, Wage Komarawidjaja, Joko P. Susanto \\ Pusat Teknologi Lingkungan, Badan Pengkajian dan Penerapan Teknologi \\ Gedung Geostech 820, Puspiptek Serpong Banten 15314, Indonesia \\ E-mail: yudhi.sgarno@bppt.go.id
}

Diterima: 29 Juni 2013; Dikoreksi: 22 Juli 2013; Disetujui: 9 Agustus 2013

\begin{abstract}
Chlorella sp known as microalgae are able to live in various water bodies, including wastewater reservoirs. This study was conducted in order to determine the adaptation of Chlorella sp on the dairy industry wastewater, which decomposes produce nutrients for the growth of Chlorella sp. In this study chlorella sp was cultured on media F/2 Guallard, dairy industry wastewater ( LS ) and industrial wastewater with nitrogen -enriched milk equivalent nitrogen in F/2 ( LSP). The study revealed that Chlorella sp grow best in media enriched with dairy waste nitrogen equivalent $F / 2$. The media LSP produces density, the concentration of $\mathrm{Chl}-\mathrm{a}$ and $\mathrm{Chl}-\mathrm{a}$ content of Chlorella sp per individual is higher than the medium F/2 and LS. Since the dairy industry waste is not treated properly will pollute the environment surrounding the industry, it is necessary to consider the possibility of utilization of Chlorella sp on the dairy industry wastewater treatment before the waste discharged into water bodies.
\end{abstract}

Keywords: Chlorell sp., industry wastewater, photosynthesis.

\begin{abstract}
Abstrak
Chlorella sp dikenal sebagai mikroalga yang mampu hidup di berbagai badan air, termasuk badan air penampung limbah cair. Kajian ini dilakukan dengan tujuan untuk mengetahui kemampuan adaptasi Chlorella sp pada limbah cair industri susu, yang jika terurai menghasilkan nutrien untuk pertumbuhan Chlorella sp. Kajian dilakukan dengan memelihara Chlorella sp pada media F/2 Guallard, limbah cair industri susu (LS) dan limbah cair industri susu yang diperkaya dengan nitrogen setara nitrogen dalam F/2 (LSP). Kajian ini mengungkapkan bahwa Chlorella sp tumbuh paling baik di media limbah susu yang diperkaya dengan nitrogen setara F/2. Media tersebut (LSP) menghasilkan kepadatan dan konsentrasi Chl-a, serta kandungan Chl-a per individu Chlorella sp yang lebih tinggi daripada media F/2 dan LS. Mengingat limbah susu yang tidak diolah dengan baik dapat menimbulkan pencemaran bagi lingkungan perairan sekitar industri itu berada, maka perlu dipertimbangkan kemungkinan pemanfaatan Chlorella sp pada pengolahan limbah industri susu di tingkat lanjutan, sebelum limbah dibuang ke badan air.
\end{abstract}

Kata kunci: Chlorella sp, industri, limbah cair, fotosintesis

\section{PENDAHULUAN}

Mikroalga atau ganggang adalah organisme perairan yang lebih dikenal dengan sebutan fitoplankton, yang umumnya merupakan spesies uniseluler yang dapat hidup soliter dan berkoloni. Salah satu jenis mikroalga yang telah banyak dikenal oleh masyarakat adalah Chlorella $s p$. Chlorella sp. Termasuk dalam kelas Chlorophyta, yakni kelas alga yang memiliki pigmen klorofil a dan klorofil b lebih dominan daripada karoten dan xantofit sehingga mikroalga dari kelas ini menunjukkan warna hijau yang jelas seperti tumbuhan tingkat tinggi.

Chlorella $s p$ adalah mikroalga uniselular yang berukuran lebih kecil dari $10 \mu \mathrm{m}$ dan hidup kosmopolitan. Chlorella sp. Yang memiliki hijau daun (klorofil-a) tersebut, dengan ketersediaan $\mathrm{H}_{2} \mathrm{O}, \mathrm{CO}_{2}$ dan sinar matahari mampu melakukan fotosintesis untuk menghasilkan energi guna biosintesis sel, pertumbuhan dan pertambahan sel, bergerak atau berpindah dan reproduksi [1]. Chlorella sp. Akan tumbuh normal pada media yang mengandung paling sedikit 19 
jenis nutrien, yang meliputi makro nutrien (nutrien yang diperlukan dalam jumbah besar) seperti karbon, hidrogen, oksigen, nitrogen, fosfor, sulfur, natrium, magnesium, kalsium. Nitrogen, fosfor, dan kalium serta mikro-nutrien (nutrien yang diperlukan dalam jumlah kecil) seperti magnesium $(\mathrm{Mg})$, besi $(\mathrm{Fe})$, tembaga $(\mathrm{Cu})$, mangan $(\mathrm{Mn})$, seng (Zn), silikon ( $\mathrm{Si})$, boron (B), molibdenum (Mo), vanadium (V) dan kobalt (Co) [2].

Chlorella sp. Dikenal masyarakat luas karena berbagai manfaatnya. Dibidang kesehatan, Chlorella sp telah dimanfaatkan sebagai makanan suplemen yang dapat menyembuhkan berbagai macam penyakit; dan dibidang perikanan telah lama dimanfaatkan sebagai makanan utama anak-anak ikan/udang di pusat/ balai benih ikan (hatchary). Selain pemanfaatan yang berhubungan langsung dengan biomasa Chlorella sp tersebut; manfaat Chlorella sp juga dapat diperoleh dari proses metabolisme, terutama pada proses fotosisntesis yang dilakukannya.

Formula-1 adalah reaksi kimia yang terjadi pada proses fotosintesis. Pengetahuan bahwa

$$
6 \mathrm{CO}_{2}+6 \mathrm{H}_{2} \mathrm{O} \underset{\mathrm{Chl}-\mathrm{a}}{\stackrel{\text { cahaya }}{\longrightarrow}} \mathrm{C}_{6} \mathrm{H}_{12} \mathrm{O}_{6}+6 \mathrm{O}_{2} .
$$

Chlorella sp akan mampu melakukan fotosintesis dengan maksimal dan effisien saat nutrien berkecukupan, maka dengan rekayasa arah keseimbangan reaksi yang terjadi; Chlorella sp. Dapat dimanfaatkan untuk menangkap karbon dioksida [3], nutrien dan logam berat [4] yang terlarut dalam badan air, termasuk badan air penampungan limbah cair industri.

Kesadaran masyarakat pada peran susu terhadap kesehatan telah meningkatkan kebutuhan susu nasional dan mendorong produsen susu untuk terus menambah kapasitas produksi dan membangun pabrik baru di Indonesia. Fenomena ini secara sosial ekonomi sangat menguntungkan namun jika peningkatan limbah cair yang ditimbulkan oleh industri pengolahan susu tidak dikelola dengan baik akan dapat mencemari lingkungan.

Limbah cair industri susu memiliki karakteristik khusus (Tabel-1). Limbah tersebut sangat mudah terurai/membusuk melepas bau dan nutrien (terutama $\mathrm{N}$ dan $\mathrm{P}$ ) sehingga jika sebelum dibuang ke perairan umum tidak diolah dengan baik akan mencemari lingkungan.

Mengingat Chlorella sp bernilai ekonomi tinggi, dan melalui fotosintesanya mampu menyerap nutrien dengan cepat dan optimal maka peluang pemanfaatan Chlorella sp. Guna menekan konsentrasi nutrien pada limbah cair industi susu, sekaligus memproduksi biomasanya perlu dilakukan.

Tabel 1. Komposisi limbah cair industri susu

\begin{tabular}{lllc}
\hline & Parameter & Unit & Konsentrasi \\
\hline 1 & $\mathrm{pH}$ & - & $6-9$ \\
2 & BOD & $\mathrm{mg} / \mathrm{l}$ & 50 \\
3 & COD & $\mathrm{mg} / \mathrm{l}$ & 250 \\
4 & TSS & $\mathrm{mg} / \mathrm{l}$ & 50 \\
5 & Lemak dan Minyak & $\mathrm{mg} / \mathrm{l}$ & 10 \\
6 & Total nitrogen & $\mathrm{mg} / \mathrm{l}$ & 10 \\
7 & Total fosfor & $\mathrm{mg} / \mathrm{l}$ & 2 \\
8 & Perbedaan suhu air & $\mathrm{oC}$ & 3 \\
\hline
\end{tabular}

Kajian ini dilakukan dengan tujuan untuk mengetahui pertumbuhan chlorella sp pada media yang terbuat dari limbah cair industri susu. Sasaran kajian ini adalah dikuasainya kemungkinan pemanfaatan chlorella sp. Sebagai penetralisir limbah cair industri susu

\section{BAHAN DAN METODE}

\subsection{Chlorella sp.}

Kajian pertumbuhan Chlorella sp. Pada limbah cair industri susu ini dilakukan di Balai Teknologi Lingkungan/BTL-BPPT di PUSPITEK Sepong. Kajian dilakukan dari bulan Agustus samai dengan September 2011. Mikroalga uji yakni Chlorella sp diperoleh dari Pusat Penelitian Oseanografi LIPI, Jalan Pasir Putih Ancol, Jakarta Utara. Sebelum diuji pertumbuhannya, Chlorella sp dibiakan dengan sistim batch, menggunakan media yang dipupuk NPK dan di aerasi terus menerus.

\subsection{Media Kultur}

Penelitian dilakukan dengan menumbuhkan Clorella sp pada 3 (tiga) media yang berbeda yakni: Media kultur standar F/2 yang dikembangkan oleh Guillard dkk[6], sehingga dalam kajian ini disebut sebagai media FG. Media FG secara umum telah diketahui sebagai media yang cocok untuk pertumbuhan Chlorella sp. Pada kajian ini Media FG digunakan sebagai pembanding kesuburan media yang lain. Kandungan hara media ini adalah seperti tersaji pada Tabel 2.

Tabel 2 Komposisi kimiawi media FG.

\begin{tabular}{llcc}
\hline & Bahan Kimia & Unit & $\mathrm{F} / 2$ \\
\hline $\mathbf{1}$ & N_NaNO3 & $\mathrm{mg} / \mathrm{L}$ & $\mathbf{1 2 . 3 5}$ \\
2 & P_NaH2PO4.H2O & $\mathrm{mg} / \mathrm{L}$ & $\mathbf{1 . 1 2}$ \\
3 & Fe_FeC13.6H2O & $\mathrm{mg} / \mathrm{L}$ & $\mathbf{0 . 6 5}$ \\
4 & EDTA_Na2EDTA.2H2O & $\mathrm{mg} / \mathrm{L}$ & $\mathbf{3 . 4 0}$ \\
5 & Cu_CuSO4.5H2O & $\mathrm{mg} / \mathrm{L}$ & $\mathbf{2 . 5 0}$ \\
6 & Mo_NaM0O4.2H2O & $\mathrm{mg} / \mathrm{L}$ & $\mathbf{1 . 8 0}$ \\
7 & Zn_ZnSO4.7H2O & $\mathrm{mg} / \mathrm{L}$ & $\mathbf{5 , 0 0}$ \\
8 & Co_COCI2.6H2O & $\mathrm{mg} / \mathrm{L}$ & $\mathbf{2 . 4 8}$ \\
9 & Mn_MnCl2.4H2O & $\mathrm{mg} / \mathrm{L}$ & $\mathbf{5 0 , 0 0}$ \\
\hline
\end{tabular}

Media LS, yakni media dibuat dari 100 persen 
limbah cair industri susu INDOLAKTO (tanpa pengenceran) yang telah mengalami proses pengolahan awal (primary treatment) selanjutnya.

Media LSP, yakni media LS ditambah dengan unsur nitrogen yang jumlahnya setara dengan nitrogen yang dikandung dalam F/2. Selanjutnya disebut media LSP.

\subsection{Kajian Pertumbuhan Chlorella sp.}

Kajian dilakukan dengan memasukan Chlorella sp. Berkepadatan $35 \times 10^{3}$ sel per milliliter kedalam 9 (sembilan) wadah yang berisi 3 (tiga) macam media dengan 3 (tiga) ulangan. Wadah media yang digunakan adalah erlernmeyer berukuran $2.000 \mathrm{ml}$ yang masing-masing diisi $1500 \mathrm{ml}$ media. Selama penelitian secara terus menerus media diaerasi dan ditempatkan dibawah 2 buah sinar lampu neon 40 Watt.

Untuk mengetahui kemampuan adaptasi Chorella $s p$ pada ketiga media tersebut, diukur perubahan kepadatan sel dan konsentrasi klorofil. Untuk menentukan kepadatan, setiap hari diambil 15 mililliter media, yang kemudian diawetkan dengan formalin. Sementara itu untuk menentukan konsentrasi klorofil setiap 3-4 hari diambil $20 \mathrm{ml}$ media kultur kemudian disaring dengan GF/C.

\subsection{Penentuan Kepadatan dan Chl-a}

Kepadatan Chlorella sp. Ditentukan dengan metode "uthermohr" setelah modifikasi Garno $[2,7]$. Chlorella sp diendapkan di chamber selama minimum 12-18 jam dan kemudian dihitung dibawah inverted microscoop pada pembesaran $600 \mathrm{X}$. Chamber pengendap adalah wadah berbentuk silinder dengan volume $5 \mathrm{ml}$ dan tinggi $1 \mathrm{~cm}$.

Khlorofil-a (Chl-a) ditentukan dengan teknik spektrofotometri; yakni dengan melarutkan sampel yang menempel pada kertas saring GF/C kedalam larutan aceton $95 \%$, dan kemudian diukur panjang gelombangnya dengan spektrofotometer.

\section{HASIL DAN PEMBAHASAN.}

Perubahan kepadatan Chlorella sp. Pada media F/2 selama penelitian disajikan pada Gambar 1. Gambar 1 menunjukkan bahwa di media F/2 dari hari ke-1 sampai hari-7 ke kepadatan clorella $s p$. Meningkat, dari $36 \times 10^{3}$ ind. Per mililliter di hari0 menjadi $1,64 \times 10^{6}$ ind. Per milliliter di hari ke7. Setelah mengalami nilai tertinggi di hari ke-7, kepadatan individu dan konsentrasi Chl-a Chlorela sp. Sedikit demi sedikit menurun dan tidak mampu naik kembali hingga kajian selesai.

Kepadatan tertinggi yang dicapai kajian ini hampir 2 (dua) kali lebih besar daripada hasil penelitian sebelumnya yang juga menggunakan media sama $(F / 2)$ dan kepadatan awal relatif sama (30-40 x $10^{3}$ sel permilliliter) namun dengan sumber $\mathrm{CO}_{2}$ dari kegiatan industri [3]. Pada kajian tersebut kepadatan tertinggi pada hari ke-7 dengan nilai $0,980 \times 10^{6}$ ind. Per milliliter[3]. Kenyataan ini mengisyaratkan bahwa pada media dengan kandungan nutiren yang sama, Chlorella $s p$ dapat tumbuh lebih baik pada media yang di aerasi daripada di media yang di injeksi dengan emisi $\mathrm{CO}_{2}$ dari kegiatan industri.

Gambar 1 juga menunjukkan bahwa biomasa dalam bentuk konsentrasi Chl-a mengalami perubahan dengan kecenderungan yang sama dengan perubahan kepadatan individu Clorella $s p$; dimana pada hari pertama tercatat $32 \mu \mathrm{g} \mathrm{Chl-a}$ per liter meningkat tajam menjadi $132 \mu \mathrm{g} \mathrm{Chl-a}$ per liter di hari ke-7 Chl-a dan kemudian turun sedikit demi sedikit menjadi 89,4 $\mu \mathrm{g}$ Chl-a per liter di saat kajian berakhir.

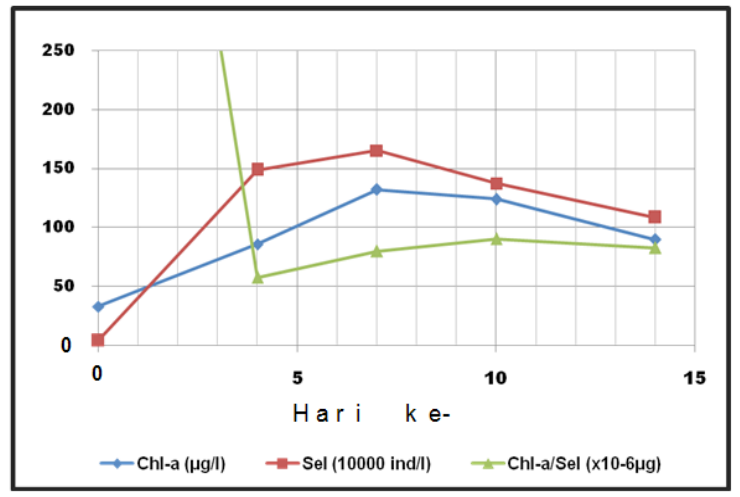

Gambar-1 Perubahan Chl-a, jumlah sel dan Chl-a/sel Chlorella sp. pada media F/2 Guallard

Kecenderungan yang terjadi pada perubahan kedua parameter biomasa (kepadatan dan Chl-a) tersebut mengisaratkan bahwa untuk pertumbuhannya Chlorella $s p$ dapat memanfaatkan dengan baik ketersediaan nutrien yang ada pada media F/2. Kesimpulan ini didukung oleh hasil analisis kimia media kultur yang menunjukkan bahwa pada hari ke4, konsentrasi $\mathrm{N}-\mathrm{NH}_{4}^{+}+\mathrm{N}^{-} \mathrm{NO}_{3}^{-}$pada media telah turun menjadi $14,0 \mathrm{mg} / \mathrm{l}$, dan pada hari ke 15 menjadi 0,20 mg/l; padahal pada awal kajian konsentrasi nitrogen adalah 17,43 mg/l. Hasil penelitian dengan kecenderungan perubahan seperti pada penelitian ini telah pula dilaporkan peneliti sebelumnya $[7,8,9]$.

Selanjutnya Gambar 1 menunjukkan bahwa kandungan klorofil-a per individu Chlorella sp pada awal kajian mengalami penurunan tajam, dari 903 $\times 10^{-6} \mu \mathrm{g} \mathrm{Chl}$-a per individu menjadi hanya $58 \mathrm{x}$ $10^{-6} \mu \mathrm{g}$ Chl-a per individu. Ini mengisyaratkan bahwa kandungan klorofil setiap individu Chlorella $s p$ di hari ke-4 jauh lebih kecil (6,5 persen) daripada individu Chlorella $s p$ di awal penelitian. Ini menunjukkan bahwa peningkatan Chl-a tidak 
sebanding dengan peningkatan kepadatan Clorella $s p$ yang diduga karena adanya individu Chl-a yang tidak sehat karena stress di awal penelitian. Fenomena ini dapat dijelaskan sebagai berikut; pada awal kajian setiap benih Chlorella sp dalam keadaaan sehat dan mengandung Chl-a yang normal. Ketika dimasukan pada media baru (F/2) sebagian benih stress atau mati sehingga sebagian benih sebenarnya tidak tumbuh namun tetap terhitung karena adanya aerasi. Benih Chlorella sp yang tidak tumbuh namun tetap terhitung ini pada hari ke-4 sebenanya sudah tidak memiliki Chl-a sehingga memperkecil rata-rata kandungan Chl-a perindividunya. Sementara itu, benih Chlorella sp yang sehat di media F/2 tumbuh cepat yang pada hari ke-4 menghasilkan individu -individu yang jauh lebih kecil daripada benih awal; sehingga meskipun jumlahnya besar namun total Chl-a tetap kecil. Kedua fenomena itulah yang menyebabkan peningkatan konsentrasi Chl -a tidak sebanding dengan peningkatan Clorella $s p[10]$.

Setelah hari ke-4 kandungan Chl-a tiap individu Clorella sp mengalami peningkatan dan kemudian cenderung menurun setelah hari ke-10. Peningkatan kandungan Chl-a tiap individu Clorella $s p$ yang sejalan dengan peningkatan konsentrasi Chl-a dan kepadatan Clorella $s p$ mengindikasikan bahwa populasi telah didominasi oleh individu Clorella sp yang sehat. Penurunan kandungan Chl-a tiap individu Clorella sp yang dimulai hari ke-11 dan seterusnya yang terjadi lebih lambat daripada mulainya penurunan Chl-a dan kepadatan, mengindikasikan bahwa meskipun densitas telah turun namun populasi masih didominasi oleh individu Clorella sp yang sehat sehingga penurunan densitas lebih cepat daripada penurunan $\mathrm{Chl}-\mathrm{a}[10]$.

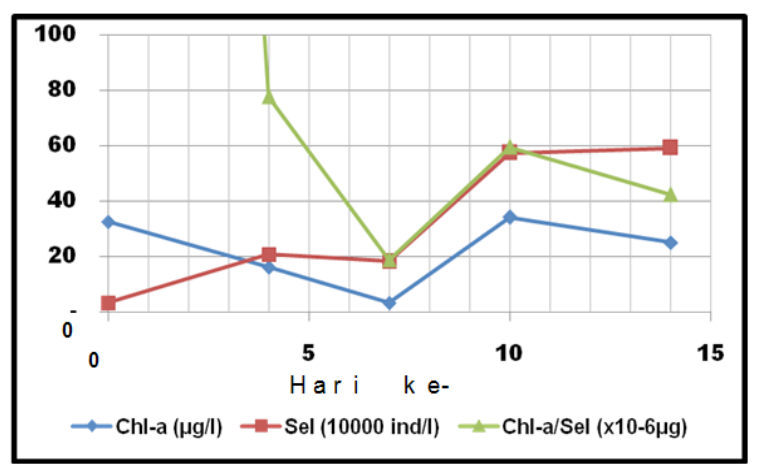

Gambar-2 Perubahan Chl-a, jumlah sel dan Chl-a/sel Chlorella sp. pada media limbah cair susu (LS).

Perubahan kepadatan Chlorella sp. Pada media limbah susu (LS) selama penelitian disajikan pada Gambar 2. Gambar 2 menunjukkan bahwa selama penelitian, kepadatan Chlorella sp. Di media limbah susu cenderung untuk meningkat terus meskipun pelan, sehingga di akhir kajian hanya menghasilkan densitas tertinggi $0,592 \times$ $10^{6}$ yang bersarnya hanya $1 / 3$ density tertinggi di media F/2. Fenomena ini terjadi diduga karena meskipun dalam konsentrasi rendah namun limbah susu mampu melepas nutrien yang dibutuhkan Chlorella sp secara terus menerus[11]

Konsentrasi Chl-a di media LS, tidak seperti di media $F / 2$ yang mengikuti kecenderungan densitas. Di media LS, konsentrasi Chl-a pada awal penelitian menurun hingga $3 \mu \mathrm{g}$ Chl-a per liter di hari ke-7 baru kemudian meningkat dengan mengikuti kecenderungan kepadatan Chlorella sp. Fenomena ini terjadi diduga karena diawal kajian, peningkatan densitas Chlorella sp lebih besar dipengaruh oleh nutrien yang disimpan dalam sel bawaan dari media pembenihan awal daripada pengaruh nutrien di media LS awal. Karena peningkatan densitas oleh nutrien tersimpan, maka individu yang dihasilkan kurang dapat berkembang dimedia LS awal tyang sangat minim nutrien. Oleh karena itu maka individu Chlorella sp. Di awal kajian terdiri dari individu yang kurang sehat dan akibatnya konsentrasi Chl -a pada periode ini mengalami penurunan. Dugaan ini diperkuat dengan kenyataan bahwa kandungan Chl-a per individu pada periode ini turun drastis dari dari $947 \times 10^{6} \mu \mathrm{g}$ Chl-a per individu menjadi hanya $19 \times 10^{-6} \mu \mathrm{g}$ Chl-a per individu. Nilai yang jauh lebih kecil daripada nilai penurunan di media F/2. Selanjutnya setelah hari ke-7 nampaknya kondisi populasi Chlorella sp telah menjadi normal dan tumbuh dibawah pengaruh nutrien hasil degradasi limbah susu, sehingga perubahan kepadatan, Chl-a dan kandungan Chl-a tiap individu menjadi selaras.

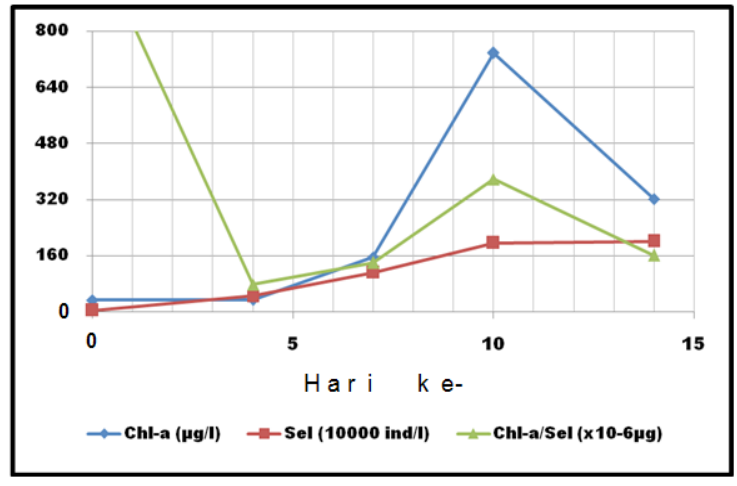

Gambar-3 Perubahan Chl-a, jumlah sel dan Chl-a/sel Chlorella sp. pada media limbah cair susu yang diperkaya dengan $\mathrm{F} / 2$ (LSP).

Perubahan kepadatan Chlorella sp. Pada media LSP yakni limbah susu yang diperkaya nitrogen setara $F / 2$ selama penelitian disajikan pada Gambar 3. Gambar 3 menunjukkan bahwa selama penelitian densitas Chlorella $s p$ cenderung meningkat terus menerus, dengan nilai $\left(2,00 \times 10^{6}\right.$ ind. Per milliliter) yang lebih besar daripada densitas di media F/G $\left(1,64 \times 10^{6}\right.$ ind. 
Per milliliter). Hal ini mengindikasikan bahwa pada awal penelitian, Chlorella $s p$ dapat tumbuh dengan baik seperti di media F/2 yang disebabkan ketersediaan nitrogen. Selanjutnya densitas Chlorella sp di media LSP tetap naik sampai akhir kajian. Kecenderungan yang tidak sama dengan kecenderungan densitas di media $F / 2$ yang turun setelah hari ke-7 diduga karena di media LSP, setelah inorganik nitrogen yang ditambahkan pada limbah susu habis, limbah susu mulai terdekomposisi dan menghasilkan nutrien yang dapat digunakan untuk melanjutkan kenaikan densitas Chlorella sp.

Konsentrasi Chl-a di media LSP, selama penelitian meningkat sampai hari ke-10 dengan konsentrasi tertinggi $738 \mu \mathrm{g}$ Chl-a per liter, Nilai ini jauh lebih tinggi daripada konsentrasi di medi F/2 yang hanya mencapai $132 \mu \mathrm{g}$ Chl-a per liter di hari ke-7. Fenomena ini mengisyaratkan bahwa pada kajian ini Chlorella sp tumbuh lebih baik di media LSP daripada di media F/2. Konsentrasi Chl-a di media LSP setelah hari ke-10 mengalami penurunan, yang diduga karena nutrien hasil dekomposisi limbah susu tidak mampu lagi memberikan nutrien dalam jumlah yang cukup untuk memenuhi kebutuhan populasi Chlorella sp yang densitasnya tinggi.

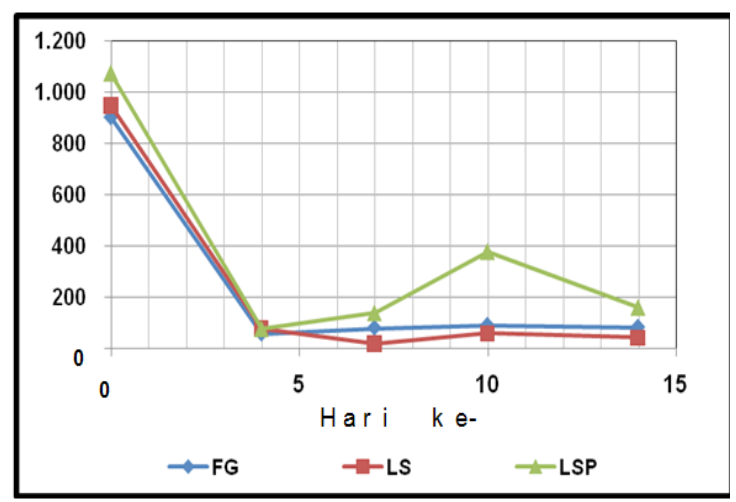

Gambar-4 Perubahan kandungan chlorofil pada setiap Chlorella sp. pada FG, LS dan LSP.

Kandungan Chl-a per individu Chlorella $s p$ di media LSP memiliki kecenderungan yang lebih mirip dengan kecenderungand di media $F / 2$ daripada di media LS, dimana Chl-a per individu turun drastis di hari ke-4 yang diiduga karena adanya individu Chlorella $s p$ yang stres seperti telah diuraikan di alinea diatas. Setelah hari ke-4 kandungan Chl-a per individu Chlorella sp di media LSP naik dan di hari ke-10 mencapai maksimal dengan nilai $378 \times 10^{-6} \mu \mathrm{g} \mathrm{Chl-a} \mathrm{per} \mathrm{individu,} \mathrm{dan}$ kemudian turun di hari terakhir menjadi $161 \times 10^{-6}$ $\mu \mathrm{g}$ Chl-a per individu. Kandungan Chl-a per individu Chlorella sp di media LSP yang selalu lebih tinggi daripada di media F/2 ini mengisyaratkan bahwa pada kajian ini Chlorella sp tumbuh lebih baik di media LSP daripada mdia F/2.
Chl-a adalah salah satu figmen pada mikroalga Chlorophyta yang memegang peranan kunci pada proses fotosintesa $[11,12]$. Keberadaan Chl -a pada mikroalga ditentukan oleh nutrien yang terlarut dalam media tumbuhnya; oleh karena itu maka kandungan Chl-a per individu mikroalga mengindikasikan pula produktifitas media hidup mikroalga tersebut. Dengan pemikian seperti itu maka untuk mengetahui tingkat produktifitas media F/2, LS dan LSP dapat dianalisis dari kandungan Chl-a per individu Chlorella sp produk media tersebut.

Gambar 4 adalah perubahan kandungan $\mathrm{Chl}$ -a per individu Chlorella sp selama penelitian di media F/2, LS dan LSP. Gambar 4 menunjukkan bahwa sampai hari ke-5, kandungan Chl-a per individu Chlorella sp yang dikultur di ke-3 media tersebut tidak menunjukkan adanya perbedaan nyata, yang diduga terjadi karena adanya stress di awal percobaan. Kandungan Chl-a per individu Chlorella sp di setiap media setelah hari ke-5 memiliki nilai yang berbeda satu dengan lainnya. Kandungan Chl-a per individu Chlorella $s p$ di media LSP selalu lebih tinggi daripada kandungan Chl-a per individu Chlorella sp di media FG dan $L S$. Sementara itu, kandungan $\mathrm{Chl}$-a per individu Chlorella $s p$ di media LS selalu lebih rendah daripada kandungan Chl-a per individu Chlorella sp di media FG dan LSP. Dengan demikian dapat disimpulkan bahwa pada kajian ini, Chlorella $s p$ hidup lebih baik di media LSP daripada di media F/2 dan LS; dan, Chlorella sp hidup lebih baik di media F/2 daripada di media LS. Perlu diperhatikan bahwa penambahan nitrogen pada limbah susu agar memiliki konsentrasi nitrogen setara dengan media F/2 ternyata telah memberikan pengaruh positif terhadap kualitas media, dimana penambahan nitrogen telah meningkatkan produktifitas media LS dan kandungan Chl-a per individu Chlorella sp.

\section{KESIMPULAN}

Pembahasan hasil kajian kultur Chlorella $s p$ dengan media $F / 2$, limbah susu (LS) dan limbah susu diperkaya nitrogen hingga setara nitrogen dalam F/2 menunjukkan bahwa media LSP adalah yang terbaik untuk produktivitas Chlorella $\mathrm{sp}$. Pada kajian ini media LSP memberikan densitas individu dan konsentrasi Chl-a serta kandungan Chl-a per individu Chlorella sp yang lebih tinggi daripada media F/2 dan LS.

Mengingat limbah susu yang tidak diolah dengan baik dapat menimbulkan pencemaran bagi lingkungan perairan sekitar industri itu berada, maka tidak ada salahnya mempertimbangkan kemungkinan pemanfaatan Chlorella sp pada pengolahan limbah industri susu di tingkat lanjutan, sebelum limbah dibuang ke badan air. 


\section{DAFTAR PUSTAKA}

1. Pranayogi, D. (200)3. Studi Potensi Pigmen Klorofil dan Karotenoid dari Mikroalga Jenis Chlophyceae. Lampung: Universitas Lampung.

2. Garno, Y.S. (1992): Experimental Study of Phytoplankton Dynamics under Different Impacts of Zooplankton and Nutrients. "Doctor Thesis". Graduated Course of the Sciences for Atmosphe and Hydrosphere School of Sciences, Nagoya University. Japan.112 pp.

3. Santoso A.D. Dan R.A. Darmawan. (2010). Studi Kemampuan Chloerella Sp. Dalam Penyerapan Gas $\mathrm{Co}_{2}$ Pada Fotobioreaktor Sistem Batch Dan Kontinyu

4. Kusrinah, (2001). Penurunan Konsentrasi Logam Berat Kadmium (Cd) Air Laut oleh Chlorella sp. "Skripsi" Jurusan Biologi, MIPA, Universitas Diponegoro.

5. World Bank. (1998). "Pollution Prevention and Abatement: Dairy Industry." Draft Technical Background Document. Environment Depart., Washington, D.C.

6. Guillard, R.R.L., (1973). Methods For Microflagellates And Nanoplankton. Handbook of Phycological Methods. Cambridge University Press, Cambridge.
7. Garno, Y.S., (1993). "Respon Fitoplankton pada Perubahan Konsentrasi Nutrient terlarut”, Dit. TPLHBPP Teknologi., 72-78 .

8. Garno Y.S. (1994). Eutrofikasi dan Pencemaran Lingkungan Perairan. Prosiding Pengelolaan Limbah dan Pemulihan Kerusakan Lingkungan, DIT. TL. BPPT, 69-78.

9. Hayes, F.R., J.A McCarter, M.L.Cameron, and Livingston. (1952). On the kinetics of phosphorus exchange in lakes. J.Ecol., 40:202-216.

10. Garno, Y.S. (1994): Dinamika Plankton dan Bahan Organik dalam Badan Air Tertutup yang dipupuk dengan dosis tinggi (Eutrofik). Prosiding Presentasi IImiah Peneliti BPP Teknologi, BPP Teknologi., 196207.

11. Hendersen B. and H.R. Markland "Decaying Lakes-The Origins and Control of Cultural Eutrofication", John \& Willey Sons Ltd. New York. Brisbane, Toronto, Singapura, 1987

12. H Goldman, C.R and A.J. Horne, "Limnology". International Student Edition. McGraw-Hill, Inc. Tokyo. 1983. 